\title{
ALUMINIUM ANALYSIS IN EYE SHADOW USING ATOMIC ABSORPTION SPECTROPHOTOMETER
}

\author{
Rini Ambarwati $a^{*}$ \\ ${ }^{a)}$ Universitas Pakuan, Bogor, Indonesia \\ ${ }^{*}$ Corresponding Author: riniambarwati2507@gmail.com
}

Article history: received 17 September 2018; revised 20 December 2018; accepted 10 January 2019

\begin{abstract}
Abstrak. Industry is a human endeavor so that goods obtained from nature can be utilized as products that have a sale value and have a profitable profit in economic terms. Material from nature has chemicals that can be used for certain purposes, such as food, fuel, fuel, fertilizer, cosmetics, etc. so that human life becomes more comfortable. A chemical industry must pay attention to environmental sustainability and is expected to process materials that are safe for the environment, as well as products produced that are environmentally friendly. In the modern cosmetics industry, eyeshadow added pearly substances that have a shiny and radiant effect, in accordance with the current trend. Pearls derived from nature are Guanine, which comes from marine fish scales, are transparent and shiny crystals like pearls. Because Guanine is difficult to obtain, the producers replace it by adding synthetic pearls, including Aluminum metal powder. Aluminum is a metal used for basic materials of household appliances, but is contained in eyeshadow which functions as a pearling agent. Research on aluminum in eye shadow cosmetics has been carried out on the market. Quantitative analysis was carried out with Atomic Absorption Spectrophotometer, the results obtained showed the presence of Aluminum with the results of all eyeshadow used as samples containing Aluminum, but the level was still below the permissible level of $10 \%$. Aluminum content contained in the eyeshadow used as a sample is between $0.35 \mathrm{mg} /$ gram $-16.952 \mathrm{mg} / \mathrm{gram}$ or $0.35 \%-1.69 \%$. The smallest one is in the Gold E color eyeshadow brand and the highest one in the Gold B brand eyeshadow
\end{abstract}

Keywords: eyeshadow; alumunium; atomic absorption spectrophotometer

\section{INTRODUCTION}

Industry is a human endeavor so that goods obtained from nature can be utilized as products that have a sale value and have a profitable profit in economic terms. Material from nature has chemicals that can be used for certain purposes, such as food, fuel, fuel, fertilizer, cosmetics, etc. so that human life becomes more comfortable. A chemical industry must pay attention to environmental sustainability and is expected to process materials that are safe for the environment, as well as products produced that are environmentally friendly [1]. In the modern cosmetics industry, eyeshadow added pearly substances that have a shiny and radiant effect, in accordance with the current trend. Pearls derived from nature are Guanine, which comes from marine fish scales, are transparent and shiny crystals like pearls. Because Guanine is difficult to obtain, the producers replace it by adding synthetic pearls, including Aluminum metal powder. (Mutiatikum [2])

Aluminum is a metal used for basic materials from household appliances such as pots, mixtures for various other metals, electric wires and various welding [3]. Aluminum is also used for window frames and aircraft frames, soft drink bottles, lid bottles of milk. So it is very dangerous if Aluminum is used as a pearl in the eyeshadow, given the true function of Aluminum [4].

Aluminum used in eye shadow can cause skin irritation, the type of which is contact dermatitis [5]. Any random and continuous use of cosmetics will cause Aluminum metal to accumulate in large quantities to irritate the skin [6]. Eyebrow shaving can cause greater irritation. Aluminum must not exceed the $10 \%$ limit [7].

\section{RESEARCH METHODS}

The tools used in this study are atomic absorption spectrophotometry, destructive and cooling flask, volume pipette, drop pipette, measuring flask, flask, ash-free filter paper, analytic scales, erlenmeyer, glass beaker, film tube, Aluminum Hollow cathode lamp and equipment other laboratory support used in the study. The material used in this study is 5 pieces of eye shadow. Standard solution of Aluminum (Al) $1000 \mu \mathrm{g} / \mathrm{mL}$, King water (Aqua regia), $\mathrm{H}_{2} \mathrm{O}_{2}$ and aqua demineralization. All chemicals used are pro analysis [8]. This study used 5 samples from eyeshadow by sharing different brands, which circulated around Cimahi and Bandung. The sample was weighed as much as 1 gram triplo. The samples were drained wet using Aqua regia $\left(\mathrm{HNO}_{3} \mathrm{p}: \mathrm{HCl}\right.$ p) $1: 3$, and $\mathrm{H}_{2} \mathrm{O}_{2}$ p, filtered with Whatman paper, then the samples were analyzed quantitatively using atomic absorption spectrophotometry. So it can be known the levels of Aluminum in the sample. (Sumardi [9]).

\section{RESULTS AND DISCUSSION}

The equation of the calibration curve is $\mathrm{y}=0.001 \mathrm{x}+$ 0.002 and $r=0.999$. The levels of Aluminum obtained from eye shadow, which is $7.52 \mathrm{mg} / \mathrm{gram} ; 8,561 \mathrm{mg} / \mathrm{gram} ; 6,143$ $\mathrm{mg} /$ gram for " $A$ " eyeshadow. 16,952 mg/gram; 12,251 mg/gram; 12,109 mg/gram for " $B$ " eyeshadow. 13,471 mg / 
gram; 14,677 mg/gram; 16,415 mg/gram for " $C$ " eyeshadow $8,476 \mathrm{mg} / \mathrm{gram} ; 9,755 \mathrm{mg} / \mathrm{gram} ; 7,502 \mathrm{mg} / \mathrm{gram}$ for " $D$ " eyeshadow. and 3,613 mg/gram; $3,517 \mathrm{mg} / \mathrm{gram} ; 10.252$ $\mathrm{mg} / \mathrm{gram}$ for " $E$ " eyeshadow.

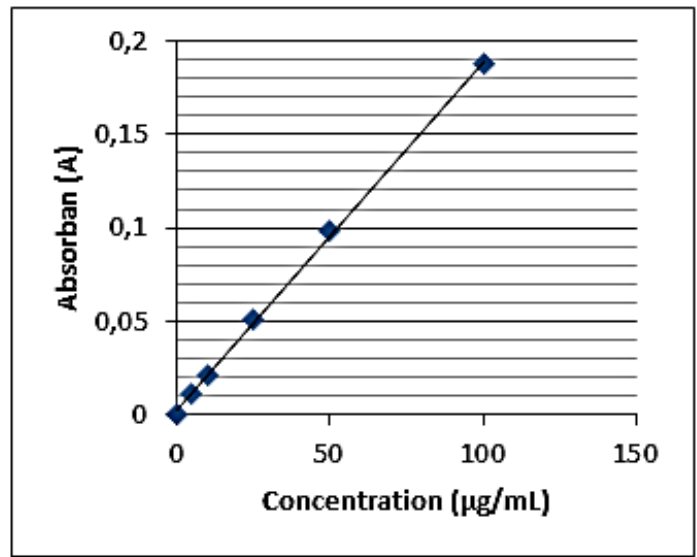

Figure. 1 Alumunium Calibration Curve

The selected samples turned out to all contain aluminum. Aluminum content (Al) contained in the eyeshadow used as a sample is between 3,517 mg / gram$16,952 \mathrm{mg} /$ gram. The smallest one is on the E Gold eyeshadow and the highest is in the Gold B eyeshadow. The most abundant sample is in the gold-colored eyeshadow brand $\mathrm{B}$, this is related to the addition of a lot of pearling agents to certain colors such as gold which indeed tends to have people think that gold is a shiny color, then added with aluminum as a pearling agent more to be more shiny.

Table 1. Alumunium Absorban Data

\begin{tabular}{|c|c|c|}
\hline Sample & Weight $(\mathrm{mg})$ & Absorban \\
\hline A & 1000,0 & 0,0772 \\
\hline A & 1005,7 & 0,0881 \\
\hline A & 1004,3 & 0,0637 \\
\hline B & 1001,6 & 0,1718 \\
\hline B & 1004,0 & 0,1250 \\
\hline B & 973,6 & 0,1199 \\
\hline C & 1013,3 & 0,1385 \\
\hline C & 1002,2 & 0,1491 \\
\hline C & 1000,9 & 0,1663 \\
\hline D & 1007,5 & 0,0874 \\
\hline D & 1005,6 & 0,1007 \\
\hline D & 1017,0 & 0,0783 \\
\hline E & 998,9 & 0,0381 \\
\hline E & 1000,7 & 0,0372 \\
\hline E & 996,9 & 0,1042 \\
\hline
\end{tabular}

In addition there are also those who have a high Aluminum content which is also a dark brown $\mathrm{C}$ brand. The level is $16,415 \mathrm{mg} / \mathrm{gram}$ which is close to the difference from the B gold brand of 16,952 mg/gram. Aluminum as a deep eyeshadow pearling agent is also added to colors other than those known as glittering gold, given also to dark colors such as dark brown, and dark red. With the aim of giving more aluminum to dark colored eyeshadow, it looks more shiny by adding aluminum as a lot of pearling agent in eyeshadow formulations. And does not give a dark effect when used. All samples contain aluminum but the levels are still below the permissible level of $10 \%$.

\section{CONCLUSION}

Research on aluminum in eye shadow cosmetics has been carried out on the market. Quantitative analysis was carried out with Atomic Absorption Spectrophotometer, the results obtained showed the presence of Aluminum with the results of all eyeshadow used as samples containing Aluminum, but the level was still below the permissible level of $10 \%$. Aluminum content contained in the eyeshadow used as a sample is between $0.35 \mathrm{mg} /$ gram- $16.952 \mathrm{mg} / \mathrm{gram}$ or $0.35 \%-1.69 \%$. The smallest one is in the Gold E color eyeshadow brand and the highest one in the Gold B brand eyeshadow. It is recommended to conduct further research on other eyeshadow samples against Aluminum as a pearling agent, and other metals such as Zinc, Bismuth, and Titanium which are often also used as eyeshadow pearling agents.

\section{REFERENSI}

[1] P. Citroreksoko, A. Taufik, A. Murharini, S. Purawisastra, and Y. Suchyadi, 2012. Kimia Terapan, 1st ed. Jakarta: Universitas Terbuka.

[2] Mutiatikum, D. 2001. Zat Pemutiara dalam Sediaan Kosmetika. Pusat penelitian dan Pengembangan Farmasi, Badan Penelitian dan Pengembangan Kesehatan. Departemen Kesehatan; Jakarta.

[3] Balsam, M.S \& Sagarin, E. 1972. Cosmetic, Science, and Technology, $2^{\text {nd }}$ ed, Willey-Interscience, New York

[4] Basset, J. 1994. Buku Ajar Vogel Kimia Analisis Kuantitatif Anorganik. Terjemahan Dr. A. Hadyana Pudjaatmaka \& Ir. L. Setiono, EGC; Jakarta

[5] Djuanda, A. 2001 Ilmu Penyait dan Kelamin. Fakultas Kedokteran Universitas Indonesia; Jakarta.

[6] Butler, H. Poucher's Perfumes, Cosmetics, and Soaps, $10^{\text {th }}$ Ed. Kluwer Academic Publisher; London.

[7] Departemen Kesehatan Republik Indonesia. 1993. Kodeks Kosmetik Indonesia, edisi VIII, Vol I; Jakarta.

[8] G, Svehla. 1990. Vogel Buku Teks Analisis Anorganik Kualitatif Makro dan Semimikro, bagian I, ed 5, terjemahan Setiono dan Hadyana Pudjaatmaka, PT. Kalman Media Pustaka; Jakarta.

[9] Sumardi. 1987. Destruksi Basah dengan Menggunakan Kombinasi Metode Basah dan Metode Kering; Warta Kimia Analitik. 